\title{
Plant-microbe interaction in aquatic system and their role in the management of water quality: a review
}

\author{
Jatin K. Srivastava ${ }^{1}$ Harish Chandra ${ }^{2} \cdot$ Swinder J. S. Kalra $^{3}$ - Pratibha Mishra ${ }^{3}$. \\ Hena Khan ${ }^{4} \cdot$ Poonam Yadav ${ }^{1}$
}

Received: 2 March 2015/ Accepted: 7 April 2016/Published online: 23 April 2016

(c) The Author(s) 2016. This article is published with open access at Springerlink.com

\begin{abstract}
Microbial assemblage as biofilm around the aquatic plant forms a firm association that largely depends upon the mutual supplies of nutrients, e.g., microbes interact with plants in an aquatic system most likely for organic carbon and oxygen, whereas plants receive defensive immunity and mineral exchange. Apart from the mutual benefits, plant-microbe interactions also influence the water quality especially at rhizosphere providing inherent ability to the aquatic system for the mitigation of pollution from the water column. The review presents and in-depth information along with certain research advancements made in the field of ecological and bio/chemical aspects of plant-microbe interactions and the underlying potential to improve water quality.
\end{abstract}

Keywords Plant-microbe interaction - Aquatic plants . Biofilm $\cdot$ Rhizosphere $\cdot$ Pollution mitigation $\cdot$ Bio/chemical interaction

Jatin K. Srivastava

jks_345@rediffmail.com

1 Academy of Science Communications, Environmental Research and Analysis (ERA), 315, SSC, Lucknow, UP 226016, India

2 High Altitude Plant Physiology Research Center, H.N.B. Garhwal University, Srinagar, Uttarakhand 246174, India

3 Department of Chemistry, Dayanand Anglo Vedic College, Civil Lines, Kanpur, UP, India

4 Department of Environmental Sciences, University of Lucknow, Lucknow, UP 226001, India

\section{Introduction}

Wetlands are the transitional zones between land and water bodies characterized by shallow overlying water-logged soils harboring rich floral and faunal diversity. The floral diversity of freshwater ecosystem includes rich diversity of macrophytes and microphytes such as phytoplankton, diatoms and other algae dominating the freshwater regimes. Aquatic macrophytes are the large plants growing in the water and at the transitional zones of land and waterways. The principal chemical constituents of surface water required for the proper growth of macro and microphytes include the optimum concentrations of major nutrients such as $\mathrm{N}\left(>45 \mathrm{mg} \mathrm{L}^{-1}\right)$ and $\mathrm{P}\left(>0.25 \mathrm{mg} \mathrm{L}^{-1}\right)$ along with organic $\mathrm{C}$ and other nutrient elements (Srivastava et al. 2008). Besides the macro and microphytes, microbial consortia exist at various levels of community generally observed as detrital microbial mat, biofilm, and planktonicmicroalgal-bacterial assemblages (Paerl and Pinckney 1996; Battin et al. 2003) and contribute substantially to the nutrient cycling (nitrification, denitrification, sulfate reduction, methanogenesis and metal ion reduction) and energy flow in aquatic ecosystem, as a feed of the zooplanktons, altering water quality and degrading the environmental pollutants (Cotner and Biddanda 2002; Battin et al. 2003; Hahn 2006). Microbial assemblage as a biofilm commonly occurs on the leaves of submerged plants, rhizosphere, especially on rhizoplane and on the solid surfaces of sediments. Several environmental conditions, such as excessive nutrients (eutrophication) their availability (Giaramida et al. 2013) and presence of toxic substances in the water affect biofilm and their structure (Calheiros et al. 2009).

Water quality of freshwater aquatic systems is subjected to the natural degradation, processes of eutrophication and 
the impacts of human activities. Voluminous research literature is available addressing the issues of aquatic pollution (Nagai et al. 2007; Camargo and Alonso 2006; Khan and Srivastava 2008; Shukla et al. 2009) and its biological remediation (Sooknah and Wilkie 2004; Nahlik and Mitsch 2006; Hadad et al. 2006; Srivastava et al. 2014) and the references therein. Furthermore, earlier scientific researches apparently indicate that most of the water quality improvement studies have been carried on the environmental pollutants and their removal either by aquatic plants (in situ and ex situ) or by microbes alone and only few reports are available indicating direct impact of the interaction of the aquatic macrophytes and microbes (Stout and Nüsslein 2010; Sharma et al. 2013; Lamers et al. 2012; Lu et al. 2014) and its possible influence on water quality (Stottmeister et al. 2003; Radhika and Rodrigues 2007; Srivastava et al. 2007; Toyama et al. 2011; Chakraborty et al. 2013). In this paper, most of the technical concepts related to the aquatic macrophytes and their interactions with microbes have been reviewed. Several aspects related to the microbes, microbial assemblages and their role in aquatic regimes have been discussed with a gist of their cumulative impact on the quality of freshwaters.

\section{Microbial assemblage (biofilm) and its role in aquatic ecosystem}

Microorganisms, numerically and biochemically dominate all inland water habitats (Hahn 2006) and proper functioning of an aquatic ecosystem is supported by the rich microbial diversity depending upon the nutrient and prevailing environmental conditions (Zehr 2010). Microbial diversity in freshwaters belongs mainly to the culturable bacterial group viz., actinobacteria, alpha-proteobacteria, beta-proteobacteria, gamma-proteobacteria, firmicutes, bacteriodetes (Calheiros et al. 2009) and archaea (Wang et al. 2008; Wei et al. 2011). Microbial assemblages are found as biofilm on solid substrata and on plant surfaces (Gagnon et al. 2007). Figures 1 and 2 show the major bacterial groups often present in the assemblage mostly in the freshwaters and the graphical structure of biofilm (the circles represent the group of bacteria and the diversity, whereas the size of circles represent the population density of different bacteria belonging to a particular group). Biofilm is a porous meshwork of slime matrix (Weber et al. 1978) formed of extracellular polymeric substance (EPS) (Fig. 2) (Branda et al. 2005), comprised of polysaccharides, proteins, nucleic acid and lipids in which microbial cells remain embedded. In biofilm, microbial cells live in a customized micro-niche in a complex microbial homeostatically stable community having a firm metabolic cooperation, which renders ecologically different characters to the microbes (Costerton et al. 1995). Microbial assemblage in a biofilm is robust and vulnerable to be altered substantially with the change of habitats and the environmental conditions (Hahn 2006; Yannarell and Triplett 2004; Kierek-Pearson and Karatan 2005). Crump and Koch (2008) showed different plant species hosting different bacterial communities. Moreover, molecular techniques such as denaturing gradient gel electrophoresis (DGGE) and terminal restriction fragment length polymorphism (TRFLP) fingerprints of PCR amplified 16S rDNA fragments can easily provide the information of overall pattern of microbial community of biofilm (Truu et al. 2009). Metagenomics studies revealed that microbes perform well in the community, i.e., consortia (Srivastava et al. 2014). In general, microbial communities in a biofilm provide plenty of opportunities to bacterial cells for exchange of genetic information through horizontal gene transfer (HGT) conferring resistance, tolerance and chemical degrading ability (Srivastava et al. 2014). Moreover, HGT is often held responsible for enhancing the competitiveness of bacteria in the natural environments (Ventura et al. 2007). The genetically stable populations of microbes in a biofilm generate varied sensitivities and responses to various anthropogenic pressures (Mcclellan et al. 2008). $\mathrm{PO}_{4}{ }^{3-}$ ions particularly influence the sensitivity of bacterial community in biofilm for toxicants (Kamaya et al. 2004; Guasch et al. 2007; Tlili et al. 2010). Additionally, Tlili et al. (2010) demonstrated the shift in the microbial community in response to toxicants such as $\mathrm{Cu}$ and diuran (herbicide), especially in conditions of nutrient deficiency.

\section{Aquatic plant-microbe interaction and its role in freshwater ecosystem}

Aquatic macrophytes are limited to the macroscopic flora including the members of four different groups: (1) emergent (e.g., Phragmites australis), (2) floating leaved (e.g., Hydrilla spp.), (3) free floating (e.g., Pistia stratiotes) and (4) submerged macrophytes (e.g., Chara spp.) (Figure 3) (Srivastava et al. 2008). The distribution of aquatic plants and microbial species largely depend up on the nutrient status of freshwaters (Wu et al. 2007; Buosi et al. 2011) in the following order: oligotrophic $>$ mesotrophic $>$ eutrophic $>$ hypertrophic. The rhizoplane (the part of root remaining in contact with water or soil) of all macrophytes is the most active zone (Davies et al. 2006; Münch et al. 2007) because of the presence of various microbial communities. Macrophytes do not affect the microbial community structure in the microcosm, providing strong evidence in support of the higher activities of natural plant-microbe interactions even in the sediments (Ahn et al. 2007). Roots of aquatic plants provide extended 
Fig. 1 Commonly present bacterial groups with most common examples in an aquatic system

Fig. 2 Pictorial representations of microbial assemblages in a biofilm

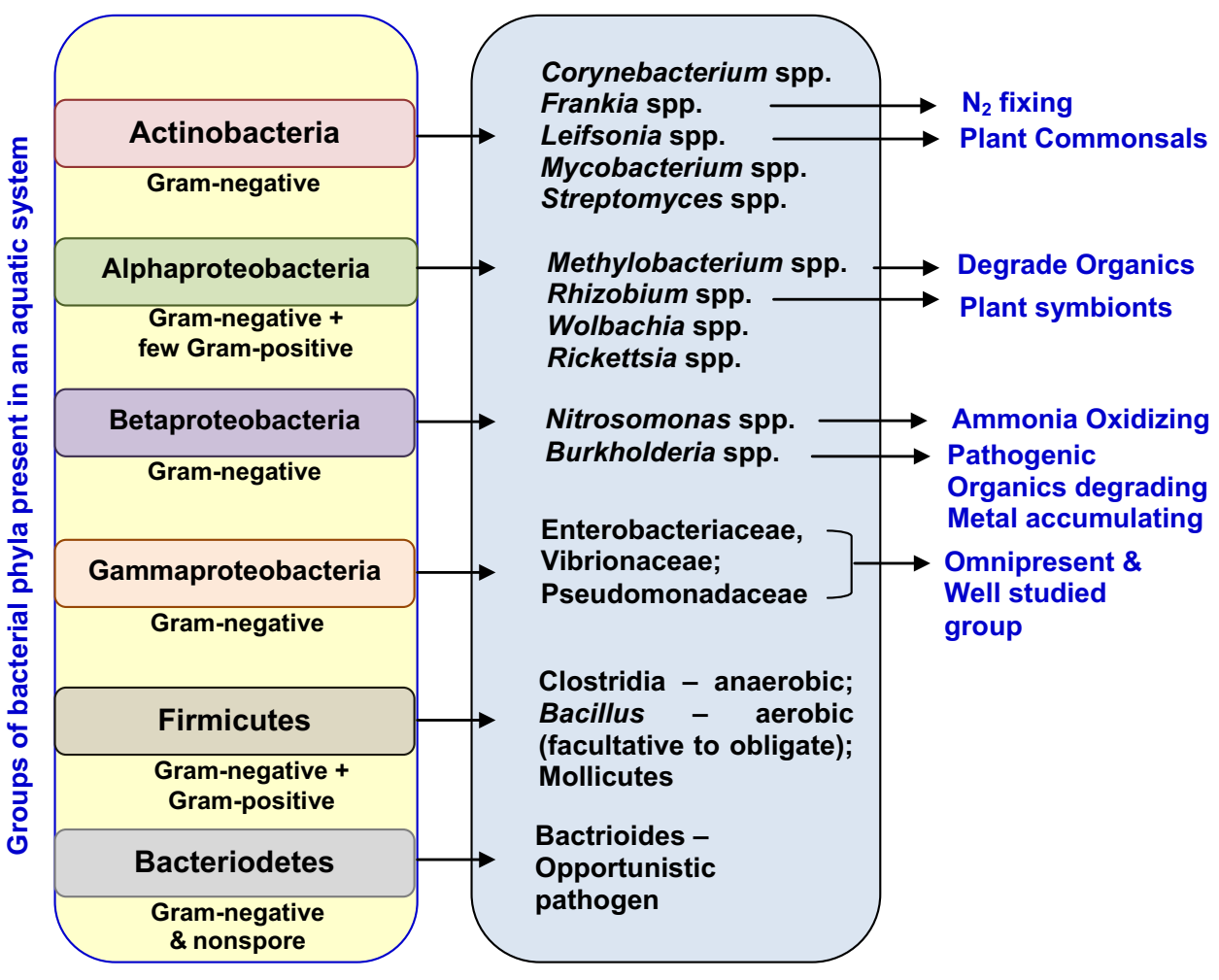

The arrangement of circles is assumed as a symbolic of number of individual members of phyla to illustrate the composition of biofilm in fresh water aquatic system

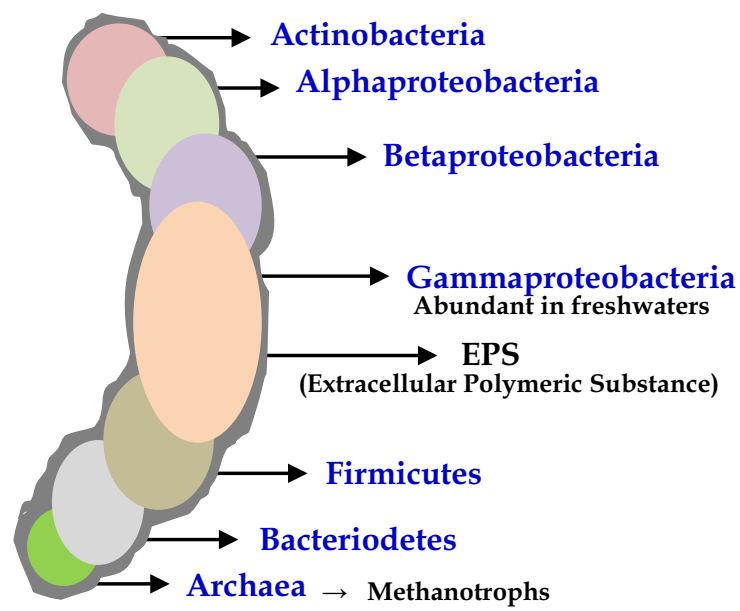

surface for benthic microbial community to rest and act as a customized niche for each microbe ensuring the continuous supply of nutrients, organic carbon and oxygen (Stottmeister et al. 2003). Similarly, aquatic plants get mineral nutrients and defensive immunity in return from the microbes forming firm interrelationships between these two. Stout (2006) demonstrated the impact of plant-microbe interaction on Lemna minor whereby bacterial association within the roots of the plant negatively influence the uptake of $\mathrm{Cd}$ metal ions to avoid the entry of this toxic metal into the plants. Plant-microbe interaction in fresh water bodies depend on several factors such as water chemistry ( $\mathrm{pH}$, electrical conductivity, salt concentrations, dissolved oxygen, dissolved organic matter, and toxic organic pollutants) (Schauer et al. 2005), redox conditions (Gray et al. 2004) and the availability of nutrients (Buosi et al. 2011; Ahn et al. 2007). Very limited information is available on the significance of plant-microbe interaction in aquatic ecosystem however; some of the typical examples of aquatic plant-microbe interactions and their role in the aquatic system are presented in Table 1. Table 1 also indicates the microbial interaction with aquatic macrophytes contributing mainly in nitrogen cycle. Rhizoplane of aquatic plants is the zone of influence which has 

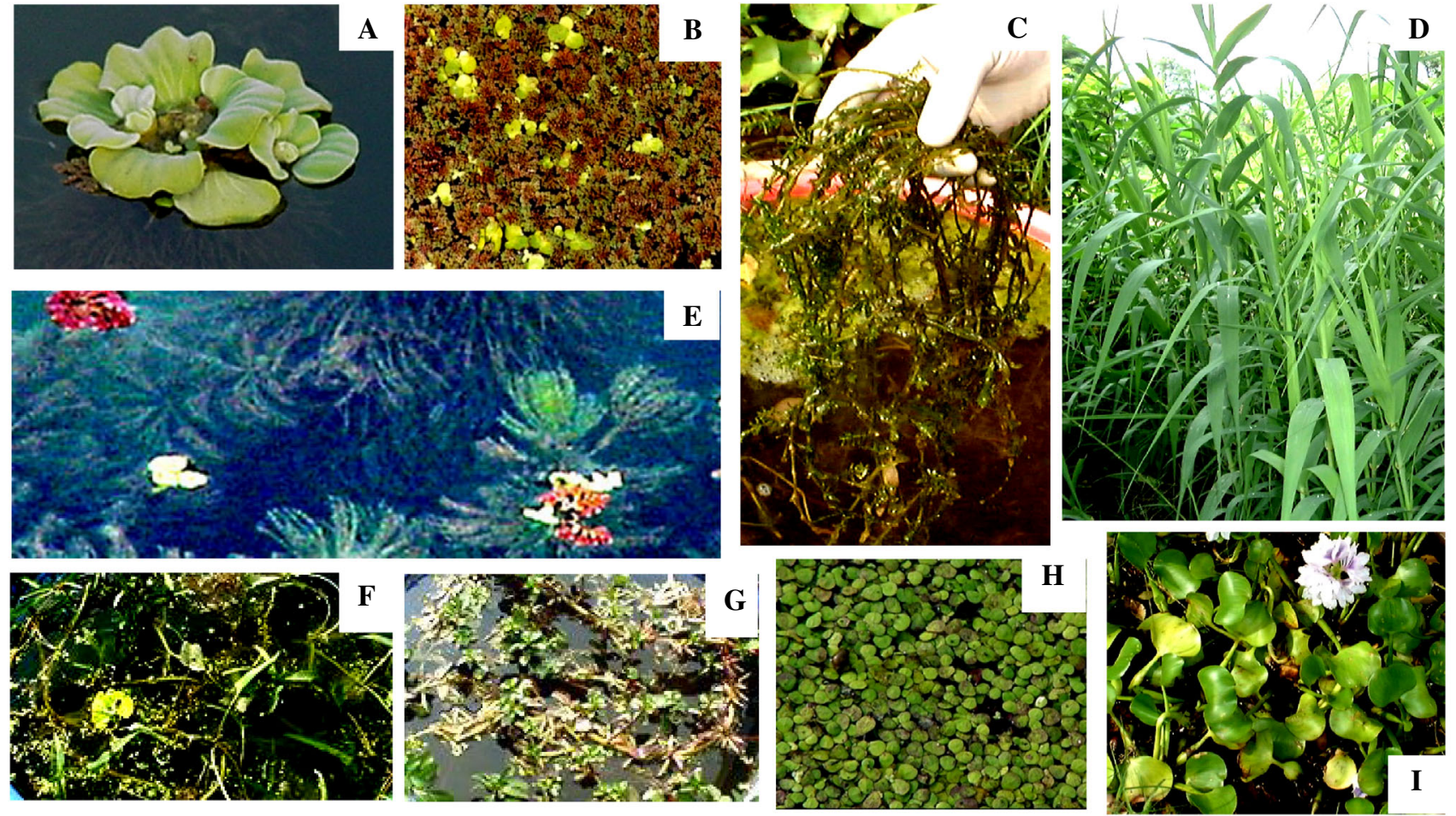

A - Pistia stratiotes; B - Azolla spp.; C - Hydrilla spp.; D - Phragmites australis; E - Chara spp.; F - Ipomea aquatic; G Ludwigia repens; H - Spirodela polyrhiza; I - Eichhornia crassipes Photo by Dr. Jatin Srivastava

Fig. 3 Some aquatic macrophytes of common occurrence in wetlands of North India

different water chemistry than rest of the water column because of high microbial activity (Stout and Nüsslein 2010). Clear evidence is apparent from the researches, e.g., Stottmeister et al. (2003); Hoang et al. (2010); Calheiros et al. (2010); Zhao et al. (2014) and from the work referred therein, for the independent and random plant-microbe interactions. This implies that in most of the aquatic regimes including the engineered wetlands, aquatic plants interact with microbes from symbiotic to parasitic, irrespective of the species of plant and microbe. Terrestrial plants release an array of chemical signals to interact with other organisms (Badri et al. 2009), whereas aquatic plants depend more on the offerings such as organic carbon and $\mathrm{O}_{2}$ (especially at rhizoplane) required primarily by the microorganisms to survive. In general, microbes form two types of symbiotic relationship with plants: (1) endophytic, involving the colonization of internal tissues of plants (Weyens et al. 2009) such as $\mathrm{N}_{2}$ fixing diazotrophs (Nielsen et al. 2001) and other nutrient assimilators AMF (arbuscular mycorrhizal fungi) (Sřaj-Kržič et al. 2006) and (2) ectophytic (microbes remain outside of the plant) such as ammonia-oxidizing bacteria (Wei et al. 2011) and methanotropic bacteria (Sorrell et al. 2002). Ectophytic interaction involving both roots as well as leaves is an important plant-microbe interaction as several biochemical reactions occurring at the interactive surface influence the elemental cycles in aquatic ecosystem (Laanbroek 2010). Figure 4 shows a comprehensive illustration of plant-microbe ectorhizospheric (ectophytic zone of influence) interaction. The oxygen is transported from shoot to root through inter-connected lacunae (Sand-Jensen et al. 2005) a part of which is released from the roots either by humidity-induced pressurized flow through or by winddriven venture mechanism (Soda et al. 2007), also known as radial oxygen loss (ROL) (Brix 1997; Inoue and Tsuchiya 2008). The ROL depends largely on plant species (Brix 1997; Stottmeister et al. 2003) and on the redox potential of water (Wiessner et al. 2002) accounting for $90 \%$ of rhizospheric oxygen stimulating the growth of aerobic nitrifying bacteria (Reddy et al. 1989; Brix 1997) and aerobic decomposition of organic matter present as plant exudates by heterotrophic bacteria. Oxygen is utilized mostly as a primary electron acceptor for energy generation (Bodelier 2003) and to carry out number of beneficial oxidation processes (Laanbroek 2010). Further the diagenesis of organic matter in sediments takes place via oxic and anoxic microbial activities with the consumption of electron acceptors such as oxygen causing an oxygen deficient zone. Under such anoxic conditions bacterial cells (facultative anaerobes) capable of using $\mathrm{NO}_{3}{ }^{1-}, \mathrm{SO}_{4}{ }^{2-}$ and $\mathrm{CO}_{2}$ as terminal electron acceptor to decompose the organic matter (Steenberg et al. 1993) 
Table 1 Common aquatic plant-microbe interaction and their role in the aquatic ecosystem

\begin{tabular}{|c|c|c|c|}
\hline Plant species & Microbial species & Role in ecosystem & References \\
\hline Azolla filiculoides & $\begin{array}{l}\text { Anabaena azollae }^{1} ; \\
{\text { Arthrobacter } \text { spp. }^{2}}^{2}\end{array}$ & $\mathrm{~N}_{2}$ fixation & $\begin{array}{l}\text { Carrapiço, }(2002)^{1} \text {; Stirk } \\
\quad \text { and van Staden }(2003)^{2}\end{array}$ \\
\hline Chara aspera & $\begin{array}{l}\text { Members of Cytophaga- } \\
\text { Flavobacteria- } \\
\text { Bacteriodetes }\end{array}$ & $\begin{array}{l}\text { Allelopathic activity } \\
\text { against algae and } \\
\text { Cyanobacteria }\end{array}$ & Hempel et al. (2008) \\
\hline Lemna minor & Pseudomonas sp. RWX31 & Denitrification & Ying-ru et al. (2013) \\
\hline Vetiveria ziznioides & Arbuscular mycorrhiza & $\begin{array}{l}\text { Allelopathic activity on } \\
\text { members of } \\
\text { Enterobacteriacae }\end{array}$ & Srivastava et al. (2007) \\
\hline Phragmites australis & Nitrosomonas & Ammonia oxidation & Okabe et al. (2012) \\
\hline Ulva australis & $\begin{array}{l}\text { Pseudoalteromonas } \\
\quad \text { tunicate } \\
\text { Roseobacter gallaciencis }\end{array}$ & $\begin{array}{l}\text { Allelopathic effect on other } \\
\text { Alage }\end{array}$ & Rao et al. (2006) \\
\hline Neptunia natans & Devosia neptuniae sp. nov. & Nitrogen fixation & Rivas et al. (2003) \\
\hline Utricularia spp. & 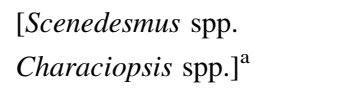 & Improving $\mathrm{P}$ supplements ${ }^{\mathrm{b}}$ & $\begin{array}{l}\text { Plachno et al. }(2012)^{\mathrm{a}} \\
\text { Sirová et al. }(2009)^{\mathrm{b}}\end{array}$ \\
\hline Hemiaulus hauki** & Richelia intracelluaris & Nitrogen fixation & Hay et al. (2004) \\
\hline Typha latifolia (L.) & Bacillus spp. & Nitrogen fixation & Biesboer (1984) \\
\hline Chlorella vulgaris & Azospirillum brasilense & PGPB & $\begin{array}{l}\text { Gonzalez and Bashan } \\
\text { (2000) }\end{array}$ \\
\hline Scenedesmus bicellularis & Pseudomonas diminuta & PGPB & Mouget et al. (1995) \\
\hline Nuphur spp. & Mesorhizobium loti & Nitrogen fixing & Wagner (2012) \\
\hline Rooted macrophytes* & $\begin{array}{l}\text { Sinorhizobium meliloti } \\
\text { P221 }\end{array}$ & IAA production in roots & Golubev et al. (2009) \\
\hline
\end{tabular}

$P G P B$ plant growth promoting bacterium

* Usually Pistia spp. do not have any symbiotic relation, Bacillus strain was introduced in the rhizosphere

** Marine alga

$1,2,{ }^{a},{ }^{b}$ superscripts corresponds to the reference as given on the extreme right of the table

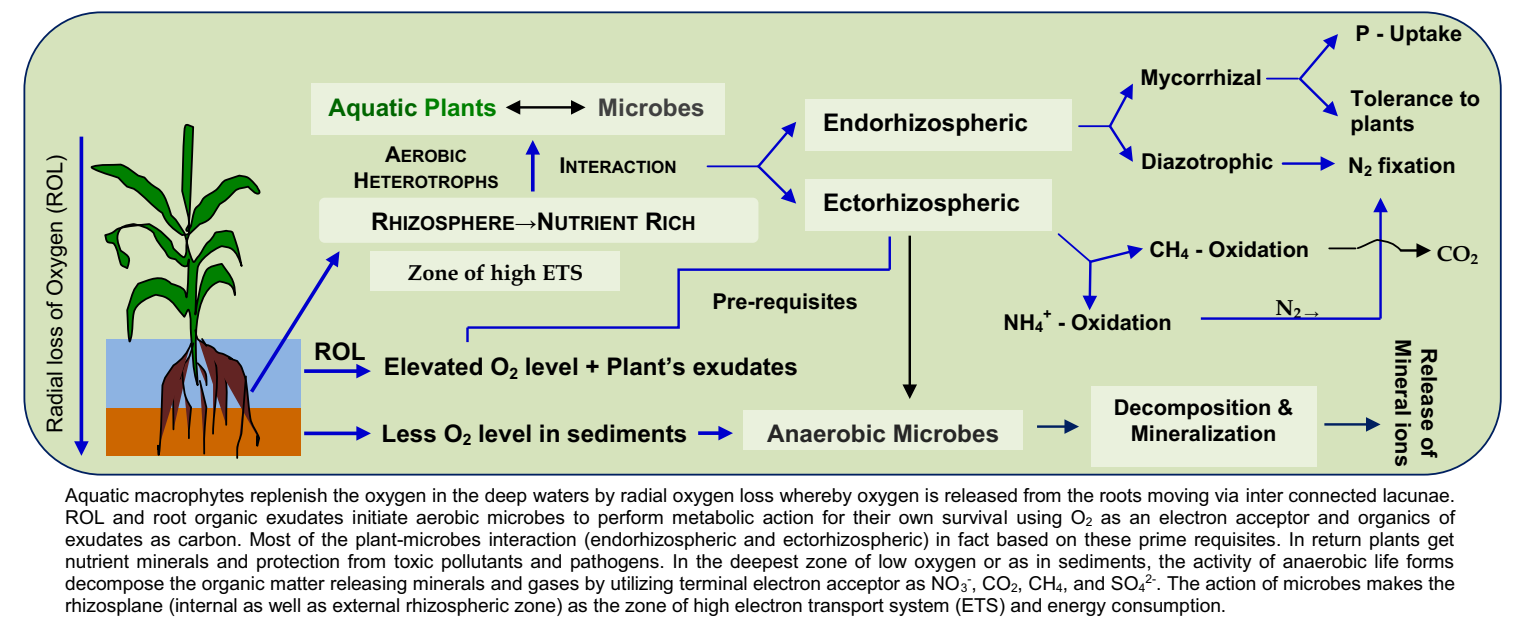

Fig. 4 Plant-microbe interactions at rhizoplane in a fresh water ecosystem

become more active causing a high electron transport system (ETS) activity in the sediments (Germ and Simčič, 2011). Methanogens produce methane $\left(\mathrm{CH}_{4}\right)$ from $\mathrm{CO}_{2}$ by reducing it with $\mathrm{H}_{2} \cdot \mathrm{CH}_{4}$ production, the lowest energy yielding process, predominates the freshwater regimes especially after the complete consumption of all the electron acceptors other than the $\mathrm{CO}_{2}$ (Rejmankova and Post 1996; Conrad 2004). 


\section{Environmental perspectives of plant-microbe interactions in an aquatic ecosystem}

The interaction of plants and microbes in the environment is quite obvious as mentioned in the previous section affecting the quality of media at large. Aquatic ecosystems provide plenty of opportunities to the plants and microbes to interact just for their survival. Environmental pollution mitigation is a cumulative effect of plant-microbe interactions in a broader sense (Pilon-Simts and Freeman 2006), also commonly known as bioremediation, which has been the most researched field in biological and environmental sciences all over the world. In general, plant-microbe interaction relies upon mutual benefits, whereas plants provide oxygen and organic carbon to the microbes in return microbes provide minerals and metabolites required by plants for their growth.

\section{Degradation of organic pollutants}

Massive field application of organic compounds such as poly-aromatic hydrocarbons (PAHs), chlorinated organic compounds, poly-brominated biphenyls ethers (PBEs) and poly-chlorinated biphenyls (PCBs) have been a major cause of contaminated environmental media (Srivastava et al. 2014) and the aquatic systems are the most vulnerable of all. Because of the catabolic activity, microbes are well-known bioremediators able to degrade virtually all classes of organic chemicals (Hiraishi 2008; Fennell et al. 2011). Cometabolism is one of the key mechanisms that microbes follow to catabolically degrade the recalcitrant organic compound to get organic carbon along with electron acceptors, available in plenty at the rhizospheric zone of terrestrial and aquatic macrophytes (Stottmeister et al. 2003). The rate of biodegradation is of second-order kinetics in natural waters and proportional to the number of microbes and amount of xenobiotics (Paris et al. 1981), whereas the microbial community largely depends upon the macrophytic species (Calheiros et al. 2009). In addition, the organic carbon, provided by the plants to the rhizospheric microbes helps degrading the complex recalcitrant organic compounds (Mori et al. 2005) such as PAHs (Mordukhova et al. 2000) and pyrenes (Jouanneau et al. 2005). Golubev et al. (2009) reported the classic example of this concerted mutual benefit whereby plants get a growth hormone indole acetic acid (IAA) as a result of rhizospheric microbial degradation of PAHs. Such observations have also been reported earlier by other researchers (Huang et al. 2004; Escalante-Espinosa et al. 2005) on different aquatic plants and sediments. Gloubev and coworkers isolated and identified the microbe such as Sinorhizobium meliloti P 221 forming an ectorhizospheric association with the aquatic plants capable to synthesize IAA via degrading PAHs.
Moreover, earlier reports of Gasol and Duarte (2000) suggest the best survival of bacteria within the productive aquatic environment of algae whereby bacteria use the algal derived carbon efficiently to grow and multiply. The increased number of bacteria cause odor and taste problems in the freshwaters (Okabe et al. 2002). Aquatic plant-associated biofilm is capable to degrade the algal-derived organics containing chiefly amines, aliphatic aldehydes and phenolics (Simpson 2009) and dissolved organic matter (DOM) (Tranvik 1998) such as PCBs (poly-chlorinated biphenyls) (Ghosh et al. 1999) and atrazine (Guasch et al. 2007). Additionally, rhizoplane of aquatic plants are also rich in ubiquitous methanotrophs a group of $\alpha$ and $\gamma$ proteobacteria, utilizing methane for energy and as carbon source (Semrau et al. 2010). Particulate methane monooxygenase (pMMO) produced in methanotrophs (e.g., Methylosinus trichosporium OB3b, Methylococcus capsulatus) degrade a wide variety of toxic organic compounds (Yoon 2010; Pandey et al. 2014), especially chlorinated ethenes (Tsien et al. 1989; Yoon 2010) via a cascade of enzymatic reactions involving the production of formaldehydes that later produce terminal compound $\mathrm{CO}_{2}$.

\section{Removal of inorganic contaminants}

Low levels of metal ions that naturally occur in aquatic systems as a result of slow leaching from soil and rocks havE no deleterious effect on aquatic biota (Zhou et al. 2008). Excessive metal ions in waters are mainly of industrial, agricultural and municipal waste origin in many parts of the world. The mobility of metal ions in the water is influenced by several bio/chemical factors including $\mathrm{pH}$ and Eh (redox potential) of water, presence of hydrated oxides of iron, metal carbonates and plant-microbe interaction as biofilm on the rhizosphere of macrophytes (Hansel et al. 2001; Carranza-Álvarez et al. 2008). Most of the metals form cations in water which adhere to the negatively charged EPS of biofilm matrix prevent the entry of metal ions into it and the plants. Most of the aquatic macrophytes possess iron plaque around the roots and submerged parts (King and Garey 1999) and sequester metal ions from water (Hansel et al. 2001). Iron plaque is layer of iron (hydr)/oxide precipitate around the plant parts caused by oxidation of iron by molecular $\mathrm{O}_{2}$ or by iron oxidizing bacteria (e.g., Ferroplasma sp. and Leptospirillum ferroxidans) (King and Garey 1999). It has been observed that radial oxygen loss depends on the root porosity of the plants which enhances the oxygen level at rhizoplane ( $\mathrm{Li}$ et al. 2011). Iron oxidizing bacteria may enhance the formation of more iron plaque. Li et al. (2011) have also demonstrated the function of root porosity, ROL, plaque formation and toxic response of As (arsenic) metalloid whereas the later was found substantially decreased 


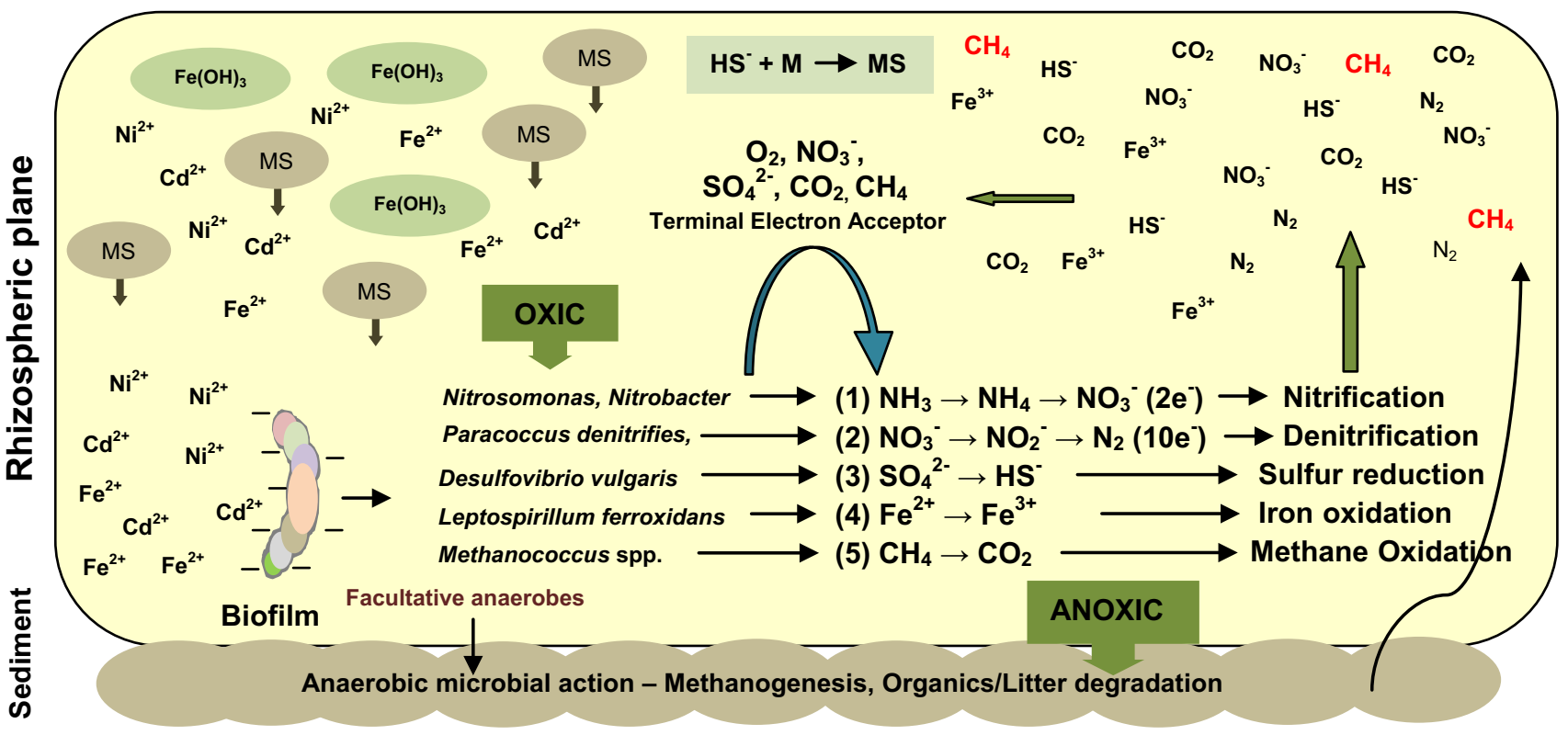

Plant-microbe interactions involve maximum action at rhizoplane. In the figure a biofilm assumed to be present on rhizosphere of an aquatic plant involve several bio/physico-chemical activities such as nitrification (1), denitrification (2), sulfate reduction (3), iron oxidation (4), and methane oxidation (5) by corresponding microbes, the resultant chemical ions as an outcome of these reactions come in to the water column and further physicochemical reactions proceed that largely affect the quality of water. Hydrogen sulfide mostly reacts with the metal cations to form metal sulfide (MS) precipitates, which fall on the surface of water body. $\mathrm{Fe}^{3+}$ react with water and form $\mathrm{Fe}(\mathrm{OH})_{3}$ that contribute in iron plaque formation on the plant surface. Under anoxic conditions most of the facultative anaerobes degrade organics and plant litter to get carbon and utilize the $\mathrm{CO}_{2}, \mathrm{SO}_{4}{ }^{2-}$, and $\mathrm{NO}_{3}{ }^{-}$as a terminal electron acceptor

Fig. 5 Bio/physico-chemical reactions at rhizoplane in an aquatic system

at increased plaque formation. After the oxidation of iron, sulfate reduction in the aquatic system is another important metal removing process (Machemer and Wildeman 1992), whereby sulfate reducing bacteria associated with aquatic macrophytes as biofilm reduce sulfate into sulfides thereby lowering the $\mathrm{pH}$ which is required by the microbial cell to biosorb the metal ions (Han and Gu 2010) from the water column. In addition, metal ions react with the hydrogen sulfide in waters (as a result of sulfate reduction) to form metal sulfide which gets precipitated in acidogenic conditions (Webb et al. 1998) and moves down to the sediments (Fig. 5) thereby sequestering metal ions from water column (Machemer and Wildeman 1992). Not only macrophytes but also algae may interact with microbes to remove contaminants from the water, e.g., Muñoz et al. (2006) observed the enhanced adsorption of toxic metals such as $\mathrm{Cu}(\mathrm{II}), \mathrm{Cd}(\mathrm{II}), \mathrm{Ni}(\mathrm{II})$ and $\mathrm{Zn}(\mathrm{II})$ by a microalga Chlorella sorokiniana having an association with bacterium Ralstonia basilensis, especially for $\mathrm{Cu}(\mathrm{II})$ adsorption because of the presence of more $\mathrm{Cu}$ binders as compared to the other metals. Mycorrhizae also form association as endophytic symbionts with most of the aquatic plants (Sřaj-Kržič et al. 2006) and enhance the uptake of $P$ and translocation of other nutrients in the plants (Thingstrup et al. 2000). Mycorrhizal associations protect the plants from toxic pollutants such as heavy metals (Srivastava et al. 2010). Srivastava et al. (2010) demonstrated the role of mycorrhizal association in Vetiver grass (a common wetland species of Indian subcontinent, South East Asia and Australia) protecting from the As (III) by blocking the membrane transport system of phosphorus, a chemical analogue of As (Meharg and Hartley-Whitaker 2002).

Plants and microbes in an aquatic system largely depend upon the availability of nutrient ions such as various mineral elements, $\mathrm{P}$ and $\mathrm{N}$ for their growth. Excessive nutrient ions cause the eutrophication of water body followed by cyanobacterial bloom and toxin production (Giaramida et al. 2013). Aquatic macrophytes take up excessive nutrient ions from the water and inhibit the growth of algae. Free floating macrophytes such as Pistia stratiotes, Eichhornia crassipes, Ipomea aquatica and Spirodela polyrhiza also play important role in removal of nutrient ions such as dissolved inorganic nitrogen such as ammonium $\mathrm{NH}_{4}{ }^{+}$. The rhizospheric association of aerobic chemoautotrophic bacteria viz., Nitrosomonas and Nitrobacter oxidizes ammonium as $\mathrm{NH}_{4}{ }^{+} \rightarrow \mathrm{NO}_{2}{ }^{-} \rightarrow$ 
Table 2 Environmental perspectives of plant-microbe interaction in aquatic ecosystem

\begin{tabular}{|c|c|c|c|c|}
\hline Plant & Microbe & Interaction type & Environmental significance & References \\
\hline Pistia stratiotes & Bacillus cereus GXBC1 & Ectorhizospheric & Enhanced $\mathrm{Cr}(\mathrm{VI})$ Uptake & Chakraborty et al. (2013) \\
\hline Phragmites austrails & $\begin{array}{l}\text { Hydrogeno phaga } S 1 ; \\
\text { Agrobacterium } \\
\text { radiobacter } S 2\end{array}$ & Ectorhizospheric & $\begin{array}{l}\text { Degradation of Acid } \\
\text { Orange- } 7\end{array}$ & Davies et al. (2006) \\
\hline Phragmites australis & Mycobacterium gilvum & Ectorhizospheric & $\begin{array}{l}\text { Degradation of } \\
\text { bezo[a]pyrine }\end{array}$ & Toyama et al. (2011) \\
\hline Ipomea aquatic & AMF & Endorhizospheric & Enhanced Cd uptake & Bhaduri and Fulekar (2012) \\
\hline Typha latifolia (L.) & $\begin{array}{l}\alpha, \beta, \gamma \text { proteobacteria; } \\
\text { Bacteroids; } \\
\text { Pseudomonads }\end{array}$ & $\begin{array}{l}\text { Endorhizospheric + } \\
\text { Ectorhizospheric }\end{array}$ & $\begin{array}{l}\text { Reduction of } \mathrm{Fe}(\mathrm{III}) \text { into } \\
\mathrm{Fe}(\mathrm{II}) \text {; enhanced } \mathrm{Cu} \\
\text { uptake }\end{array}$ & $\begin{array}{l}\text { Ye et al. (2001); Carranza- } \\
\text { Álvarez et al. (2008); Li } \\
\text { et al. (2011) }\end{array}$ \\
\hline Lemna aoukikusa & $\begin{array}{l}\text { Acinetobacter } \\
\text { calcoaceticus }\end{array}$ & Ectorhizospheric & Active phenol degradation & Yamaga et al. (2010) \\
\hline \multirow[t]{3}{*}{ Eichhornia crassipes $\mathrm{M}$. } & Nitrobacteria irancium & Ectorhizospheric & $\begin{array}{l}\text { Enhance } \mathrm{Cr} \text { and } \mathrm{Zn} \text { uptake } \\
\quad \text { (aerial) }\end{array}$ & Abou-Shanab et al. (2007) \\
\hline & Bacillus cereus & & $\begin{array}{l}\text { Enhanced Mn uptake in } \\
\text { roots }\end{array}$ & \\
\hline & Ochrobactrum anthropi & & $\begin{array}{l}\text { Enhanced } \mathrm{Cr} \text { and } \mathrm{MN} \\
\text { uptake in roots }\end{array}$ & \\
\hline Phragmites communis & Microbacterium sp. & Endorhizospheric & $\begin{array}{l}\text { Degrade Chloropyriphos } \\
\quad(<60 \%)\end{array}$ & Chen et al. (2012) \\
\hline $\begin{array}{l}\text { Nymphaea spp. } \\
\text { Najas spp. } \\
\text { Potamogetone crispus }\end{array}$ & $\begin{array}{l}\text { Pseudomonas spp.; } \\
\text { Paenibacillus spp.; } \\
\text { Enterobacter spp. }\end{array}$ & & $\begin{array}{l}\text { Degrade pesticides such as } \\
\text { Chloropyrifos and } \\
\text { Fenpropathria. Depend } \\
\text { largely on the plant's part } \\
\text { of isolation }\end{array}$ & \\
\hline Chlorella sorokiniana & $\begin{array}{l}\text { Pseudomonas migulae, } \\
\text { Sphingomonas } \\
\text { yanoikuyae }\end{array}$ & Ectorhizospheric & $\begin{array}{l}\text { Enhanced degradation of } \\
\text { Phenol, Phenanthrene, } \\
\text { salicylate }\end{array}$ & Borde et al. (2003) \\
\hline Chlorella sorokiniana & Ralstonia basilensis & Endophytic symb. & $\begin{array}{l}\text { Enhanced uptake of } \mathrm{Cu} \\
\text { metal }\end{array}$ & Muñoz et al. (2006) \\
\hline Rooted macrophytes & Methylosinus trichosporium & Ectorhizospheric & Degrade trichloroethylene & Tsien et al. (1989) \\
\hline
\end{tabular}

$\mathrm{NO}_{3}{ }^{-}$(Wetzel 2001). The presence of predominant ammonia-oxidizing bacteria (AOB) (Wei et al. 2011) and archaea (AOA) on the rhizoplane having amoA gene (Herfor et al. 2007) plays a vital role in nitrification and denitrification (Wang et al. 2009). Environmental significance of the plant-microbe interactions have been widely studied in engineered (constructed) wetlands (Kadlec et al. 2000; Vymazal et al. 2001; Stottmeister et al. 2003; Truu et al. 2005; Nahlik and Mitsch 2006; Vymazal 2007; Münch et al. 2007). Table 2 presents examples of plant-microbe interaction of aquatic environment and their ability to mitigate pollution in the waters depending on the type of interactions.

\section{Future studies}

Future studies on plant-microbe interaction and its role in environmental remediation and/or restoration in general are of utter importance and may include the metagenomics and characterization of microbial population associated with rhizoplane of aquatic plants needing lot of technological knowledge advancements. Second, it would be quite interesting to know the behavior of plant-microbe interaction at rhizoplane of free floating aquatic macrophytes under elevated atmospheric $\mathrm{CO}_{2}$ and at elevated ambient temperature and on the development of new interactive combinations in freshwater regimes. More studies are required to understand the structure and function of microbial community in a biofilm interacting with particular plant species, e.g., influence of any toxic chemical on microbial assemblages present in the vicinity, microbial community 6shift during climate change and environmental perspectives of newly developed transgenic plant-microbe interactions.

\section{Conclusion}

In aquatic systems plant-microbe interaction is common, especially on the rhizoplane. Plants secrete several organic chemicals (plant exudates) containing amino- 
acids, polysaccharides, lipids, phenolic compounds and nucleic acids in their surroundings for protecting the growing soft tissues, for mineral uptake depending upon the local electrochemical environment and to attract microbes forming an association of characteristic features performing specific actions. The nature of these interactions varies from positive to negative, depending upon their relationships. Additionally, several microbial communities interact with each other including members of actinobacteria, $\alpha, \beta, \gamma$ and $\Delta$ proteobacteria, firmicutes, bacteriodetes and archaea and remain in a continuous layer of exo-polymeric substance (EPS) forming a matrix of microbial network (biofilm). The structure of microbial assemblage differs on different plant species depending upon the nature and availability of organic carbon and oxygen level at rhizoplane. In deep waters, rooted macrophytes continuously replenish the loss of oxygen as a result of microbial and chemical consumption by supplying through the plant's interconnected lacunae right from shoot to root where the $\mathrm{O}_{2}$ is released, also known as radial oxygen loss (ROL). The ROL at rhizoplane render it a high electron transport (ETS) zone where $\mathrm{O}_{2}$ acts as electron acceptor required for the survival of aerobic life forms; however, in the absence or in low oxygen level (as in sediments) several other electron acceptors such as $\mathrm{CO}_{2}, \mathrm{CH}_{4}$ and $\mathrm{NO}_{3}{ }^{-}$support anaerobic life forms. There is a sharp oxic-anoxic interface near the rhizoplane as most of the facultative anaerobes survive at this zone and are critical for water chemistry (Fig. 4). In an aquatic system, rhizoplane is the site of active nitrification, denitrification, sulfur reduction, iron oxidation, methanogenesis, methanotrophism and many more bio/physicochemical reactions. Apart from the bio/physico-chemical actions, individual aquatic plant species possess a unique and a set pattern of micro-flora whereas both the specie interact for their survival making the resources present in the surrounding available and indirectly helps remediating the environmental pollutants to a greater extent. For example, bacterial species degrade PAHs to synthesis indole acetic acid (IAA) which is plant growth promoting hormone, and mycorrhizal interaction enhances the nutrient uptake and protects the plants from toxic metals by avoiding their direct entry presumably by altering membrane transport channels.

\section{Compliance with ethical standards}

Conflict of interest There is no conflict of interest of any kind.

Open Access This article is distributed under the terms of the Creative Commons Attribution 4.0 International License (http:// creativecommons.org/licenses/by/4.0/), which permits unrestricted use, distribution, and reproduction in any medium, provided you give appropriate credit to the original author(s) and the source, provide a link to the Creative Commons license, and indicate if changes were made.

\section{References}

Abou-Shanab RAI, Angle JS, Van-Berkum P (2007) Chromate tolerant bacteria for enhanced metal uptake by Eichhornia crassipes (Mart.). Int J Phytoremediat 9:91-105

Ahn C, Gillevet PM, Sikaroodi M (2007) Molecular characterization of microbial communities in treatment microcosm wetlands as influenced by macrophytes and phosphorus loading. Ecol Indic 7(4):852-863

Badri DV, Weir TL, van-der Lelie D, Vivanco JM (2009) Rhizospheric chemical dialogues: plant-microbe interactions. Curr Opin Biotechnol 20:642-650

Battin TJ, Kaplan LA, Newbold JD, Hensen CME (2003) Contributions of microbial biofilms to ecosystem processes in stream mesocosm. Nature 426:439-442

Bhaduri AM, Fulekar MH (2012) Assessment of arbuscular mycorrhizal fungi on the phytoremediation potential of Ipomea aquatic on cadmium uptake. 3 Biotech 2(3):193-198

Biesboer DD (1984) Nitrogen fixation associated with natural and cultivated sands of Typha latifolia L. (Typhaceae). Am J Bot 71(4):505-511

Bodelier PLE (2003) Interactions between oxygen-releasing roots and microbial processes in flooded soils and sediments. In: de Kroon H, Visser EJW (eds) Root ecology. Series: ecological studies, vol 168. Springer, Berlin, pp 331-362

Borde X, Guieysse B, Delgado O, Munoz R, Hatti-Kaul R, NugierChauvin C, Patin H, Mattiasson B (2003) Synergistic relationships in algal-bacterial microcosms for the treatment of aromatic pollutants. Biores Technol 86(3):293-300

Branda S, Vik A, Friedman L, Kolter R (2005) Biofilms: the matrix revisited. Trends Microbiol 13:20-26

Brix H (1997) Do macrophytes play a role in constructed treatment wetlands? Water Sci Technol 35:11-17

Buosi PRB, Pauleto GM, Lansac-Tóha FA, Velho LFM (2011) Ciliate community associated with aquatic macrophyte roots: effects of nutrient enrichment on the community composition and species richness. Eur J Protistol 47(2):86-102

Calheiros CSC, Duque AE, Moura A, Henriques IS, Correia A, Rangel AOSS, Castro PML (2009) Changes in the bacterial community structure in two-stage constructed wetlands with different plants for industrial wastewater treatment. Biores Technol 100(13):3228-3235

Calheiros CSC, Teixeira A, Pires C, Franco AR, Duque AF, Crispim LFC, Moura SC, Castro PML (2010) Bacterial community dynamics in horizontal flow constructed wetlands with different plants for high salinity industrial waste water polishing. Water Res 44(17):5032-5038

Camargo JA, Alonso Á (2006) Ecological and toxicological effects of inorganic nitrogen pollution in aquatic ecosystems: a global assessment. Environ Int 32:831-849

Carranza-Álvarez C, Alonso-Castro AJ, Alfaro-De La Torre MC, Garcĺa-De La Cruz RF (2008) Accumulation and distribution of heavy metals in Scirpus americanus and Typha latifolia from an artificial lagoon in San Luis Potosí, México. Water Air Soil Pollut 188:297-309

Carrapiço F (2002) The Azolla-Anabaena-Bacteria system as a natural microcosm. Proceedings of SPIE Astrobiology Conference, July 29-30, 2001. vol. 4495, pp 261-265

Chakraborty R, Mitra AK, Mukherjee S (2013) Synergistic chromium bioremediation by Water Lettuce (Pistia) and bacteria (Bacillus cereus GXBC-1) interaction. J Biol Chem Res 30(2):421-431

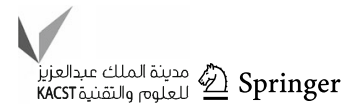


Chen W-M, Tang Y-Q, Mori K, Wu X-L (2012) Distribution of culturable endophytic bacteria in aquatic plants and their potential for bioremediation in polluted waters. Aquat Biol 15:99-110

Conrad R (2004) Methanogenic microbial communities associated with aquatic plants. In: Varma A, Abbott L, Werner D, Hampp R (eds) Plant surface microbiology. Springer, Berlin, Heidelberg, pp 35-50

Costerton JW, Lewandowski Z, Caldwell DE, Korber DR, Lappinscott HM (1995) Microbial biofilms. Ann Rev Microbiol 49:711-745

Cotner JB, Biddanda BA (2002) Small players, large role: microbial influence on biogeochemical processes in pelagic aquatic ecosystems. Ecosystems 5:105-121

Crump BC, Koch EW (2008) Attached bacterial populations shared by four species of aquatic angiosperms. Appl Environ Microbiol 74(19):5948-5957

Davies LC, Pedro IS, Novais JM, Martins-Dias S (2006) Aerobic degradation of acid orange 7 in a vertical flow constructed wetlands. Water Res 40(10):2055-2063

Escalante-Espinosa E, Gallegos-Martinez ME, Favela-Torres E, Gutierrez-Rojas M (2005) Improvement of the hydrocarbon phytoremediation rate by Cyperus laxus Lam. inoculated with a microbial consortium in a model system. Chemosphere 59:405-413

Fennell DE, Du S, Liu H, Liu F, Häggblom MM (2011) Dehalogenation of polychlorinated dibenzo-p-dioxins and dibenzofurans, polychlorinated biphenyls and brominated flame retardants and potential as a bioremediation strategy. In: Moo-Young M, Butler M, Webb C, Moreira A, Grodzinski B, Cui ZF, Agathos S (eds) Comprehensive biotechnology, 2nd edn. Pergamon Press, Oxford, pp 136-149

Gagnon V, Chazarenc F, Comeau Y, Brisson J (2007) Influence of macrophyte species on microbial density and activity in constructed wetlands. Water Sci Technol 56(3):249-254

Gasol JM, Duarte CM (2000) Comparative analyses in aquatic microbial ecology: how far do they go? FEMS Microbiol Ecol 31:99-106

Germ M, Simčič T (2011) Vitality of aquatic plants and microbial activity of sediment in an oligotrophic lake (Lake Bohinj, Slovenia). J Limnol 70(2):305-312

Ghosh U, Weber AS, Jensen JN, Smith JR (1999) Granular activated carbon and biological activated carbon treatment of dissolved and sorbed polychlorinated biphenyls. Water Environ Res 71(2):232-240

Giaramida L, Manage PM, Edwards C, Singh BK, Lawton LA (2013) Bacterial communities' response to microcystins exposure and nutrient availability-linking degradation capacity to community structure. Int Biodeterior Biodegrad 84:111-117

Golubev SN, Schelud'ko AV, Muratova AY, Makarov OE, Turkovskaya OV (2009) Assessing the potential of rhizobacteria to survive under phenanthrene pollution. Water Air Soil Pollut 198(1-4):5-16

Gonzalez LE, Bashan Y (2000) Increased growth of the microalga Chlorella vulgaris when coimmobilized and cocultured in alginate beads with the plant growth promoting bacterium Azospirillum brasilense. Appl Environ Microbiol 66(4):1527-1531

Gray ND, Comaskey D, Miskin IP, Pickup RW, Suzuki K, Head IM (2004) Adaptation of sympatric Achromatium spp. to different redox conditions as a mechanism for coexistence of functionally similar sulphur bacteria. Environ Microbiol 6:669-677

Guasch H, Lehmann V, Van-Beusekom B, Sabater S, Admiraal W (2007) Influence of phosphate on the response of periphyton to atrazine exposure. Arch Environ Contam Toxicol 52(1):32-37

Hadad HR, Maine MA, Bonetto CA (2006) Macrophyte growth in a pilot-scale constructed wetland for industrial wastewater treatment. Chemosphere 63:1744-1753
Hahn MW (2006) The microbial diversity of inland waters. Curr Opin Biotechnol 17:256-261

Han X, Gu J (2010) Sorption and transformation of toxic metals by microorganisms. In: Mitchell R, Gu J (eds) Environmental microbiology. Wiley Blackwell, Hoboken

Hansel CM, Fendorf S, Sutton S, Newville M (2001) Characterization of Fe plaque and associated metals on the roots of mine-waste impacted aquatic plants. Environ Sci Technol 35(19):3863-3868

Hay ME, Parker JD, Burkepile DE, Caudill CC, Wilson AE, Hallinan $\mathrm{ZP}$, Chequer AD (2004) Mutualisms and aquatic community structure: the enemy of my enemy is my friend. Ann Rev Ecol Evol Syst 35:175-197

Hempel M, Blume M, Blindow I, Gross EM (2008) Epiphytic bacterial community composition on two common submerged macrophytes in brackish waterand fresh water. BMC Microbiol 8:58. http://www.biomedcentral.com/1471-2180/8/58

Herfor L, Schouten S, Abbas B, Veldhuis MJW, Coolen MJL, Wuchter C, Boon JP, Herndl GJ, Sinninghe Damsté JS (2007) Variations in spatial and temporal distribution of Archaea in the North Sea in relation to environmental variables. FEMS Microbiol Ecol 62(3):242-257

Hiraishi A (2008) Biodiversity of dehalorespiring bacteria with special emphasis on polychlorinated biphenyl/dioxin dechlorinators. Microbes Environ 23:1-12

Hoang H, Yu N, Toyama T, Inoue D, Sei K, Ike M (2010) Accelerated degradation of a variety of aromatic compounds by Spirodela polyrhiza-bacterial associations and contribution of root exudates released from S. polyrhiza. J Environ Sci 22(4):494-499

Huang X-D, El-Alawi Y, Penrose DM, Glick BR, Greenberg BM (2004) A multi-process phytoremediation system for removal of polycyclic aromatic hydrocarbons from contaminated soils. Environ Pollut 130:465-476

Inoue TM, Tsuchiya T (2008) Interspecific differences in radial oxygen loss from the roots of three Typha species. Limnol 9:207-211

Jouanneau Y, Willison JC, Meyer C, Krivobok S, Chevron N, Besombes J-L, Blake G (2005) Stimulation of pyrene mineralization in freshwater sediments by bacterial and plant bioaugmentation. Environ Sci Technol 39:5729-5735

Kadlec RH, Knight RL, Vymazal J, Brix H, Cooper P, Haberl R (2000) Constructed wetlands for pollution control-processes, performance, design and operation. IWA Scientific and Technical Report No. 8. IWA Publishing, London

Kamaya Y, Takada T, Suzuki K (2004) Effect of medium phosphate levels on the sensitivity of Selenastrum capricornutum to chemicals. Bull Environ Contam Toxicol 73:995-1000

Khan SA, Srivastava J (2008) Interaction of ions in water affects water quality of freshwater lake: a case study of major lakes of North India. Environmentalist 28:217-221

Kierek-Pearson K, Karatan E (2005) Biofilm development in bacteria. Adv Appl Microbiol 57:79-111

King GM, Garey MA (1999) Ferric iron reduction by bacteria associated with the roots of freshwater and marine macrophytes. Appl Environ Microbiol 65(10):4393-4398

Laanbroek HJ (2010) Methane emission from natural wetlands: interplay between emergent macrophytes and soil microbial processes: a mini-review. Ann Bot 105:141-153

Lamers LPM, van Diggelen JMH, Camp HMO, Visser EW, Lucassen ECHET, Vile MA, Jetten MSM, Smolders AJP, Roelofs JGM (2012) Microbial transformations of nitrogen, sulfur, and iron dictate vegetation composition in wetlands: a review. Front Microbiol. 3:154. doi:10.3389/fmicb.2012.00156

Li H, Ye ZH, Wei ZJ, Wong MH (2011) Root porosity and radial oxygen loss related to arsenic tolerance and uptake in wetland plants. Environ Pollut 159(1):30-37

Lu Y, Zhou Y, Nakai S, Hosomi M, Zhang H, Kronzucker HJ, Shi W (2014) Stimulation of nitrogen removal in the rhizosphere of 
aquatic duckweed by root exudate components. Planta 239(3):591-603. doi:10.1007/s00425-013-1998-6

Machemer SD, Wildeman TR (1992) Adsorption compared with sulphide precipitation as metal removal processes from acid mine drainage in a constructed wetland. Contam Hydrol 9:115-131

Mcclellan K, Altenburger R, Schmitt-Jansen M (2008) Pollution induced community tolerance as a measure of species interaction in toxicity assessment. J Appl Ecol 45:1514-1522

Meharg AA, Hartley-Whitaker J (2002) Arsenic uptake and metabolism in arsenic resistant and nonresistant plant species. New Phytol 154:29-43

Mordukhova EA, Sokolov SL, Kochetkov VV, Kosheleva IA, Zelenkova NF, Boronin AM (2000) Involvement of naphthalene dioxygenase in indole-3-acetic acid biosynthesis by Pseudomonas putida. FEMS Microbiol Lett 190:279-285

Mori K, Toyama T, Sei K (2005) Surfactants degrading activities in the rhizosphere of giant duckweed ("Spirodela polyrrhiza"). Jpn J Water Treat Biol 41:129-140

Mouget J-L, Dakhama A, Lavoie MC, de-la Noüe J (1995) Algal growth enhancement by bacteria: is consumption of photosynthetic oxygen involved? FEMS Microbiol Ecol 18:35-43

Münch Ch, Neu T, Kuschk P, Röske I (2007) The root surface as the definitive detail for microbial transformation processes in constructed wetlands-a biofilm characteristic. Water Sci Technol 56(3):271-276

Muñoz R, Alvarez MT, Muñoz A, Terrazas E, Guieysse B, Mattiasson B (2006) Sequential removal of heavy metals ions and organic pollutants using an algal-bacterium consortium. Chemosphere 63(6):903-911

Nagai T, Imai A, Matsushige K, Yokoi K, Fukushima T (2007) Dissolved iron and its speciation in shallow eutrophic lake and its inflowing rivers. Water Res 41:775-784

Nahlik AM, Mitsch WJ (2006) Tropical treatment wetlands dominated by free-floating macrophytes for water quality improvement in Costa Rica. Ecol Eng 28:246-257

Nielsen LB, Finstek K, Welsh DT, Donelly A, Herbert RA, de Wit R, Lomstein BA (2001) Sulphate reduction and nitrogen fixation rates associated with roots, rhizomes and sediments from Zostera noltli and Spartina maritime meadows. Environ Microbiol 3:63-71

Okabe S, Kokazi T, Watanabe Y (2002) Biofilm formation potentials in drinking waters treated by different advanced treatment processes. Water Sci Technol 2(4):97-104

Okabe S, Nakamura Y, Satoh H (2012) Community structure and in situ activity of nitrifying bacteria in Phragmites rootassociated biofilms. Microbes Environ 27(3):288-292

Paerl HW, Pinckney JL (1996) A mini review of microbial consortia: their roles in aquatic production and biogeochemical cycling. Microb Ecol 31(3):225-247

Pandey VC, Singh JS, Singh DP, Singh RP (2014) Methanotrophs: promising bacteria for environmental remediation. Int J Environ Sci Technol 11(1):241-250

Paris DF, Steen WC, Baughman GL, Barnett-Jr JT (1981) Second-order model to predict microbial degradation of organic compounds in natural waters. Appl Environ Microbiol 41(3):603-609

Pilon-Simts EAH, Freeman JL (2006) Environmental cleanup using plants: biotechnological advances and ecological considerations. Front Ecol Environ 4(4):203-210

Płachno BJ, Łukaszek M, Wołowski K, Adamec L, Stolarczyk P (2012) Aging of Utricularia traps and variability of microorganisms associated with that microhabitat. Aquat Bot 97:44-48

Radhika KP, Rodrigues BF (2007) Arbuscular mycorrhizae in association with aquatic and marshy plant species in Goa, India. Aquat Bot 86(3):291-294

Rao D, Webb JS, Kjelleberg S (2006) Microbial colonization and competition on the marine alga Ulva australis. Appl Environ Microbiol 72:5547-5555
Reddy LG, Patrick WH, Lindau CW (1989) Nitrification-denitrification at the plant root-sediment interface in wetlands. Limnol Ocean 34:1004-1013

Rejmankova E, Post R (1996) Methane in sulfate-rich and sulfatepoor wetland sediments. Biogeochemistry 54:57-70

Rivas R, Willems A, Subba-Rao NS, Mateos PF, Dazzo FB, Kroppenstedt RM, Martínez-Molina E, Gillis M, Velázquez E (2003) Description of Devosia neptuniae sp—nov. that nodulates and fixes nitrogen in symbiosis with Neptunia natans, an aquatic legume from India. System. Appl Microbiol 26(1):47-53

Sand-Jensen K, Pedersen O, Binzer T, Borum J (2005) Contrasting oxygen dynamics in the freshwater isoetid Lobelia dortmanna and the marine seagrass Zostera marina. Ann Bot 96:613-623

Schauer M, Kamenik C, Hahn MW (2005) Ecological differentiation within a cosmopolitan group of planktonic freshwater bacteria (SOL cluster, Saprospiraceae, Bacteroidetes). App Environ Microbiol 71:5900-5907

Semrau JD, DiSpirito AA, Yoon S (2010) Methanotrophs and copper. FEMS Microbiol Rev 34:496-531

Sharma R, Sharma K, Singh N, Kumar A (2013) Rhizosphere biology of aquatic microbes in order to access their bioremediation potential along with different aquatic macrophytes. Rec Res Sci Technol 5(1):29-32

Shukla OP, Rai UN, Dubey S (2009) Involvement and interaction of microbial communities in the transformation and stabilization of chromium during the composting of tannery effluent treated biomass of Vallisneria spiralis L. Biores Technol 100:2198-2203

Simpson DR (2009) Biofilm processes in biologically active carbon water purification. Water Res. 42:2839-2848

Sirová D, Borovec J, Černá B, Rejmánková E, Adomec L, Vrba J (2009) Microbial community development in the traps of aquatic Utricularia spp. Aquat Bot 90(2):129-136

Soda S, Ike M, Ogasawara Y, Yoshinaka M, Mishima D, Fujita M (2007) Effects of light intensity and water temperature on oxygen release from roots into water lettuce rhizosphere. Water Res 41:487-491

Sooknah RD, Wilkie AC (2004) Nutrient removal by floating aquatic macrophytes cultured in anaerobically digested flushed dairy manure wastewater. Ecol Eng 22(1):27-42

Sorrell BK, Downes MT, Stanger CL (2002) Methanotrophic bacteria and their activity on submerged aquatic macrophytes. Aquat Bot 72(2):107-119

Sřaj-Kržič N, Pongrac P, Klemenc M, Kladnik A, Regvar M, Gaberščik A (2006) Mycorrhizal colonization in plants from intermittent aquatic habitats. Aquat Bot 85:331-336

Srivastava J, Chandra H, Singh N (2007) Allelopathic response of Vetiveria zizanioides (L.) Nash on members of the family Enterobacteriaceae and Pseudomonas spp. Environmentalist 27:253-260

Srivastava J, Gupta A, Chandra H (2008) Managing water quality with aquatic macrophytes. Rev Environ Sci Bio/technol 7:255-266

Srivastava J, Shukla D, Chand V, Naraian R, Chandra H, Nautiyal AR (2010) Mycorrhizal colonization affects the survival of Vetiveria zizanioides (L.) Nash grown in water containing As(III). CleanSoil Air Water 38(8):771-774

Srivastava J, Naraian R, Kalra SJS, Chandra H (2014) Advances in microbial bioremediation and the factors influencing the process. Int J Environ Sci Technol 11(6):1787-1800

Steenberg C, Sweerts JP, Cappenberg T (1993) Microbial biogeochemical activities in lakes: stratification and eutrophication. In: Ford $\mathrm{T}$ (ed) Aquatic microbiology - an ecological approach. Blackwell Scientific Publications, Boston, pp 69-100

Stirk WA, vanStaden J (2003) Occurrence of cytokinins like compounds in two aquatic ferns and their exudates. Environ Exp Bot 49:77-85

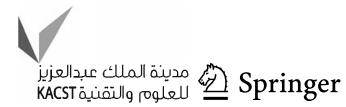


Stottmeister U, Wießner A, Kuschk P, Kappelmeyer U, Kästner M, Bederski O, Müller RA, Moormann H (2003) Effects of plants and microorganisms in constructed wetlands for wastewater treatment. Biotechnol Adv 22:93-117

Stout LM (2006) Influence of plant associated microbial communities on heavy metal uptake by the aquatic plant Lemna minor. Doctrol Dissertation for UMass Amherst. Paper AAI3242356. http://scholarworks.umass.edu/dissertations/AAI3242356. Accessed 1 Jan 2006

Stout LM, Nüsslein K (2010) Biochemical potential of aquatic plantmicrobe interactions. Curr Opin Biotechnol 21:339-345

Thingstrup I, Kahiluoto H, Jakoben I (2000) Phosphate transport by hyphae of field communities of arbuscular mycorrhizal fungi at two levels of P fertilization. Plant Soil 221:181-187

Tlili A, Bérardb A, Rouliera J, Volata B, Montuellea B (2010) $\mathrm{PO}_{4}{ }^{3-}$ dependence of the tolerance of autotrophic and heterotrophic biofilm communities to copper and diuron. Aquat Toxicol 98:165-177

Toyama T, Furukawa T, Maeda N, Inoue D, Sei K, Mori K, Kikuchi S, Ike M (2011) Accelerated biodegradation of pyrene and bezo[a]pyrene in the Phragmites australis rhizosphere by bacteria-root exudates interactions. Water Res 45:1629-1638

Tranvik LJ (1998) Degradation of dissolved organic matter in humic waters by bacteria. In: Hessen DO, Tranvik LJ (eds) Aquatic humic substances-book series, ecological studies. Springer, Berlin, Heidelberg, pp 259-283

Truu J, Nurk K, Juhanson J, Mander U (2005) Variation of microbiological parameters within planted soil filter for domestic wastewater treatment. J Environ Sci Health A 40:1191-1200

Truu M, Juhanson J, Truu J (2009) Microbial biomass activity and community composition in constructed wetlands. Sci Total Environ 407:3958-3971

Tsien HC, Brusseau GA, Hanson RS, Waclett LP (1989) Biodegradation of trichloroethylene by Methylosinus trichosporium OB3b. Appl Environ Microbiol 55(12):3155-3161

Ventura M, Canchaya C, Tauch A, Chandra G, Fitzgerald GF, Chater KF, vanSinderen D (2007) Genomics of actinobacteria: tracing the evolutionary history of an ancient phylum. Microbiol Mol Biol Rev 71(3):495-548

Vymazal J (2007) Removal of nutrients in various types of constructed wetlands. Sci Total Environ 380:48-65

Vymazal J, Balcarova J, Doušova H (2001) Bacterial dynamics in the subsurface constructed wetland. Water Sci Technol 44(11-12):207-209

Wagner SC (2012) Biological nitrogen fixation. Nat Educ Knowl 3(10): 15

Wang $\mathrm{Y}$, Inamori $\mathrm{R}$, Kong $\mathrm{H}$, Xu K, Inamori $\mathrm{Y}$, Kondo $\mathrm{T}$, Zhang $\mathrm{J}$ (2008) Influence of plant species and wastewater strength on constructed wetland methane emissions and associated microbial populations. Ecol Eng 32:22-29

Wang Y, Ke X, Wu L, Lu Y (2009) Community composition of ammonia-oxidizing bacteria and archaea in rice field soil as affected by nitrogen fertilization. System Appl Microbiol 32(1):27-36
Webb JS, McGinness S, Lappin-Scott HM (1998) Metal removal by sulphate-reducing bacteria from natural and constructed wetlands. J Appl Microbiol 84:240-248

Weber W, Pribazari M, Melson G (1978) Biological growth on active carbon: an investigation by scanning electron microscopy. Environ Sci Technol 12:817

Wei B, Yu X, Zhang S, Gu L (2011) Comparison of the community structures of ammonia-oxidizing bacteria and archaea in rhizoplanes of floating aquatic macrophytes. Microbiol Res 166:468-474

Wetzel RG (2001) Limnology, 3rd edn. Academic Press, New York

Weyens N, van-der Lelie D, Taghavi S, Vangronsveld J (2009) Phytoremediation: plant-endophyte partnerships take the challenge. Curr Opin Biotechnol 20:248-254

Wiessner A, Kuschk P, Kastner M, Stottmeister U (2002) Abilities of helophyte species to release oxygen into rhizospheres with varying redox conditions inlaboratory-scale hydroponic systems. Int J Phytorem 4:1-15

Wu X, Xi W, Ye W, Yang H (2007) Bacterial community composition of a shallow hypertrophic freshwater lake in China revealed by $16 \mathrm{~S}$ rRNA gene sequences. FEMS Microbiol Ecol 61:85-96

Yamaga F, Washio K, Morikawa M (2010) Sustainable biodegradation of phenol by Acinetobacter calcoaceticus P23 isolated from the rhizosphere of duckweed Lemna aoukikusa. Environ Sci Technol 44(16):6470-6474

Yannarell AC, Triplett EW (2004) Within and between lake variability in the composition of bacterioplankton communities: investigations using multiple spatial scales. Appl Environ Microbiol 70:214-223

Ye ZH, Cheng KC, Wong MH (2001) Copper uptake in Typha latifolia as affected by iron and manganese plaque on the root surface. Can J Bot 79(3):314-320

Ying-ru Z, Yu-fang L, Hai-lin Z, Wei-ming S (2013) Aerobic denitrifying characteristics of duckweed rhizosphere bacterium RWX3. Afr J Microbiol Res 7(3):211-219

Yoon S (2010) Towards practical application of methanotrophic metabolism in chlorinated hydrocarbon degradation green house gas removal and immobilization of heavy metals. Doctoral Dissertation. Department of Environmental Engineering. University of Michigan, USA

Zehr JP (2010) Microbes in earth's aqueous environments. Front Microbiol 1(4):1-2

Zhao D, Luo J, Zeng J, Wang M, Yan W, Huang R, Wu QL (2014) Effects of submerged macrophytes on the abundance and community composition ofammonia-oxidizing prokaryotes in a eutrophic lake. Environ Sci Pollut Res 21(1):389-398

Zhou Q, Zhang J, Fu J, Shi J, Jiang G (2008) Biomonitoring: an appealing tool for assessment of metal pollution in the aquatic ecosystem. Analyt Chim Acta 606:135-150 